\title{
Bacteriuria in asthmatics on long-term steroid therapy
}

\author{
J. B. WoOD* \\ M.A., B.M., M.R.C.P. \\ Medical Registrar, \\ New End Hospital, London, N.W.3
}

\author{
JONATHAN BROSTOFF \\ M.A., B.M., M.R.C.P. \\ Registrar to the Allergy Department, \\ St Mary's Hospital, London, W.2
}

\author{
Alan Percival $\dagger$ \\ M.A., B.M., B.Ch. \\ Senior Registrar, Department of Bacteriology, \\ St Mary's Hospital, London, W.2
}

Treatment with glucocorticoids may cause increased susceptibility to infections (Lepper, 1962). We have studied patients with bronchial asthma to discover whether the incidence of bacteriuria was higher in those treated with steroids than in those who were not.

\section{Subjects}

The urine of 171 patients attending an allergy department for advice about bronchial asthma was examined. Most were out-patients and many were in good health when seen. The diagnosis of bronchal asthma was based on a history of wheezing, breathlessness and difficulty in breathing, varying considerably from day to day and markedly relieved by sympathomimetic amines, theophylline compounds or glucocorticoids. If there was doubt about the reversibility of the airways obstruction, objective evidence was obtained with the Wright peak-flow meter or by spirometry before and after inhalations of isoprenaline or several days' treatment with steroids.

Eighty-three patients were taking steroids for persistent asthma ; allergic factors were thought to be important in five. The steroid prescribed was usually prednisone and the daily dose ranged from 2.5 to $25 \mathrm{mg}$, with a mean of $9 \mathrm{mg}$. Duration of treatment ranged from a few weeks to 11 years, with a mean of $2 \frac{3}{4}$ years.

Eighty-eight patients were not taking steroids. Allergic factors were considered to be important in thirty-nine, most of whom experienced rhinorrhoea

\footnotetext{
*Formerly Registrar to the Allergy Department, St Mary's Hospital, London, W.2.

$\dagger$ Present address: Department of Bacteriology, University of Liverpool, Liverpool 3.
}

and asthma in the summer and gave a positive skin response to pollen extracts.

An attempt was made to match the steroidtreated patients with non steroid-treated patients of the same age and sex. This was only partially successful. The steroid-treated group contained more elderly patients of both sexes and fewer young females than the non steroid-treated group. The age and sex distribution is shown in Table 1.

None of the patients was taking antibiotics.

TABLE 1

Age and sex distribution of the patients studied (numbers in parentheses are those with significant bacteriuria)

\begin{tabular}{|c|c|c|c|c|}
\hline \multirow{2}{*}{$\begin{array}{l}\text { Age } \\
\text { (years) }\end{array}$} & \multicolumn{2}{|c|}{ Steroid treated } & \multicolumn{2}{|c|}{ Not on steroids } \\
\hline & Male $F$ & Female & Male & Female \\
\hline $\begin{array}{l}11-20 \\
21-30 \\
31-40 \\
41-50 \\
51-60 \\
61-70 \\
71+ \\
\end{array}$ & $\begin{array}{r}3 \\
7(1) \\
6 \\
8 \\
10 \\
6 \\
2 \\
\end{array}$ & $\begin{array}{r}1 \\
3 \\
9 \\
10 \\
9 \\
8 \\
1 \\
\end{array}$ & $\begin{array}{l}5 \\
8 \\
8 \\
8 \\
9 \\
0 \\
1\end{array}$ & $\begin{aligned} & 6(1) \\
& 7 \\
& 11(1) \\
& 12 \\
& 9 \\
& 3(1) \\
& 1 \\
&\end{aligned}$ \\
\hline $\begin{array}{l}\text { Significant } \\
\text { bacteriuria }\end{array}$ & 1 & 0 & $\mathbf{0}$ & 3 \\
\hline Total & 42 & 41 & 39 & 49 \\
\hline
\end{tabular}

\section{Methods}

The patients were given a sterile wide-necked jar and sterile swabs moistened with a dilute solution of cetrimide and chlorhexidine for prior cleansing of the penis or vulva. They collected their own mid-stream specimens in the clinic toilet.

Urine specimens reached the laboratory within $1 \mathrm{hr}$ of collection. White cells were counted using 
uncentrifuged urine and a haematological counting chamber. Bacterial counts were performed on uncentrifuged urine by a semi-quantitative technique using sterilized adsorbent paper strips (Leigh \& Williams, 1964). In addition an aliquot of urine was centrifuged at $2500 \mathrm{rev} / \mathrm{min}$ for $15 \mathrm{~min}$, the supernatant tested for protein by adding $25 \%$ sulphosalicyclic acid and the deposit cultured on blood and MacConkey agar.

More than ten white cells per cubic millilitre was considered to be an excess (Little, 1964) and bacterial counts above $100,000 / \mathrm{ml}$ to constitute a significant bacteriuria. Whenever a specimen contained excess white cells, protein or bacterial counts above $10,000 / \mathrm{ml}$, a second specimen of urine was obtained. One exception was a woman not taking steroids whose urine contained excess cells but no protein or bacteria. She could not subsequently be traced.

\section{Results}

Four patients had a significant bacteriuria, one only in the group treated with steroids. The other three were women with seasonal asthma whose bacteriuria was persistent. One had a gross excess of white cells whilst the urine of the other two contained between three and ten white cells per cubic millilitre. Two of them also had persistent proteinuria. The patient receiving steroids had bacteriuria on one occasion without proteinuria or excess cells, and a repeat specimen was entirely normal. In addition, five other patients had persistent proteinuria without infection.

\section{Discussion}

The overall incidence of significant bacteriuria in this study was $2.4 \%$ which is lower than the $4.8 \%$ reported in unselected medical outpatients by Kass (1962). Considering the females alone, the incidence was $3.3 \%$ and this is even less than the $4.4 \%$ found in general female populations of Jamaica and Wales (Kass, 1962). There is therefore nothing in our series to suggest that bronchial asthma increases the incidence of bacteriuria.

Relating the bacteriuria to steroid therapy, the incidence was lower in the treated group than in the untreated group despite the average age of the former patients being higher and their asthma more severe.

We conclude that glucocorticoids in the doses used have not increased the incidence of bacteriuria.

\section{Summary}

The urine of patients with bronchial asthma was examined and cultured. Significant bacteriuria was no more common than has been reported in the general population.

Treatment with steroids was not associated with an increase of infection.

\section{Acknowledgments}

We wish to thank Dr H. Shire, Dr H. Hughes, Dr M. A. Ganderton and Dr L. McEwen for allowing us to study their patients, and the nursing staff of the Allergy Department for their help. We also wish to thank Dr A. W. Frankland for encouragement and advice during this study.

\section{References}

KASs, E.H. (1962) Pyelonephritis and bacteriuria. A major problem in preventive medicine. Ann. intern. Med. 56, 46.

Leigh, D.A. \& Williams, J.D. (1964) Method for the detection of significant bacteriuria in large groups of patients. J. clin. Path. 17, 498.

LePPer, M.H. (1962) Prophylaxis in patients receiving adrenal steroid therapy. J. chron. Dis. 15, 691.

Litrle, P.J. (1964) A comparison of the urinary white cell concentration with the white cell excretion rate. Brit. J. Urol. 36, 360 . 